of nucleoproteins and labile plant viruses from leaves and their susceptibility to degradation by salt were discussed by $J$. W. Lyttleton.

The chemistry of thiols and disulphides is a prominent feature of protein chemistry and was exhaustively discussed. S. J. Leach and J. M. Swan described the important analytical advances made in this field with the aid of the polarograph and the preparative applications of sulphite in the presence of an oxidizing agent, such as cupric ions. The various methods of splitting disulphide bonds and their application in the extraction of soluble proteins from wool were discussed by J. M. Gillespie, I. J. O'Donnell and E. O. P. Thompson, and H. Lindley reported on the varying reactivity of the disulphide bonds of insulin, J. M. Creeth and D. J. Winzor were concerned with the specificity of the reaction of iodine with the sulphydryl groups of ovalbumin, while the important role of thiols in disulphide interchange reactions was clearly apparent in the experiments of F. J. R. Hird, R. Frater and J. R. Yates on the nature of cohesive forces in dough. Disulphide interchange was also responsible for the inhibition of several - $\mathrm{SH}$ enzymes by 'sulphanilamide disulphides' in an investigation reported by $\mathrm{E}$. Boeri and L. Brighenti.

The physico-chemical characterization of proteins isolated from naturally occurring mixtures was covered in a further series of papers. The aggregation and disaggregation of soluble proteins and the changes induced during denaturation figured prominently in the discussions of papers presented by J. M. Creeth and L. W. Nicol on urease, by B. S. Harrap, I. J. O'Donnell and E. F. Woods on soluble wool proteins and by H. A. McKenzie on various enzymes and globular proteins. The various techniques used to follow conformation changes were critically examined and it became clear that the behaviour of a particular protein in any given system was not necessarily indicative of the behaviour of other proteins in the same system. The surface denaturation of proteins was discussed by F. MacRitchie and the application of the spread monolayer techniques to a comparison of the surface ehemical properties of various cereal proteins was described by N. W. Tschoegl. The preparative applications of electrophoresis were illustrated by the work of J. F. O'Dea on the isolation of components of serum while P. R. Carnegie and R. L. M. Synge described the electrophoretic behaviour of cupric complexes of oligopeptides and a possible method for selectively isolating dipeptides from mixtures of peptides.

Chromatography as an aid in the purification of proteins was introduced by A. G. M. Marr, who described the fractionation of serum proteins on 'DEAE-cellulose'. D. H. Simmonds has applied this technique very successfully to the water-soluble flour proteins and he also reported amino-acid analyses of the various fractions using ion-exchange chromatography with an automatic recording apparatus capable of handling eight ion-exchange columns eluted simultaneously. The continued interest of chemists in the quantitative analysis of protein constituents was evident in this paper and that of J. H. Bradbury on an alternative method requiring paper chromatography of dinitrophenyl amino-acids. This method was particularly applicable to the estimation of amide groups.

G. Coleman and W. H. Elliot described their work on the synthesis of $\alpha$-amylase by Bacillus subtilis and C. J. Shepherd discussed the effect of inhibitors of protein synthesis in Aspergillus nidulans.

A feature of the symposium was a lecture by Dr. R. L. M. Synge on "Naturally Occurring Peptides and Their Biological Significance". Although the search for naturally occurring peptides has not been intensive it was apparent from the stimulating survey by Dr. Synge that many unusual types of small peptide are already known. He went on to stress the necessity for quantitative data in the study of protein synthesis and expressed concern at the lack of experimental documentation for many of the generalizations by biochemists regarding the synthesis of proteins. A spirited discussion ensued and was continued in a subsequent session on protein synthesis.

Participants in the symposium were fortunate in having a range of papers presented covering most of the rapidly growing areas of investigation in the protein field and it may be hoped that similar conferences will be held in the future.

E. O. P. Thompson

\title{
ELECTRONICS EXHIBITION
}

$\mathrm{T}$ HE fourteenth Exhibition of Electronic Devices, organized by the Northern Division of the Institution of Electronics, was held at the Manchester College of Science and Technology during July 9-15. This annual exhibition is now well established and it provides an opportunity for new electronic apparatus to be demonstrated in rather less crowded conditions than obtain at the Physical Society Exhibition held in London during January.

A lecture programme was associated with the exhibition and, as is to be expected, a substantial part of this programme was devoted to transistor techniques. However, topics of general scientific interest were by no means excluded, and lectures on the argon chromatograph, on photographic densitometry and on the use of X-rays for micro-analysis were well attended.

The exhibition was divided into a manufacturers' section and a research section, the research exhibits forming much the sinaller part of the whole. A relatively small number of research exhibits, especially from universities, has also been evident at the Physical Society Exhibition. Although research exhibits are of considerable general interest, and of special interest to those working in related fields, it is probable that for scientific workers as a whole the more important function of an exhibition of this type is to show instruments that are currently available. In the manufacturers' section this year's exhibition was notable for the extent of the exhibits of the various electronic agencies. These agencies handle the products of a number of manufacturers and they hold stocks of instruments and components. In the case of one agency the display occupied a whole room and included examples of the products of some sixty manufacturers.

Included in the new equipment on show were examples of 'second generation' oscilloscopes. Until 
very recently, British manufacturers have been unable to offer high-performance oscilloscopes having trace brightness and amplifier band-width suitable for the display of single-pulses having fractional microsecond duration. This has meant that workers in such fields as nuclear physics and high-speed computing have either obtained equipment from North America or have constructed their own display systems. New types of oscilloscopes are now available from Messss. Cossors, EMI, Marconi Instruments and Solartron. The cathode-ray tubes are mostly of the post-deflexion acceleration type and run at voltages of $6-10 \mathrm{kV}$., amplifier band-widths are 10-20 Mc./s., and the deflexion sensitivity at full gain is about $100 \mathrm{mV}$. per $\mathrm{cm}$. This specification is adequate for all but the fastest applications, and for these, two manufacturers are offering oscilloscopes with distributed amplifiers having a band-width from d.c. to $40 \mathrm{Mc} / \mathrm{s}$. Messrs. Cossor and Heathkit showed kits of parts that can be assembled to make items of test gear such as valve-voltmeters and simple oscilloscopes. The kits normally employ printed circuits, which simplify the wiring, and can be assembled with semi-skilled labour. A wide variety of silicon devices are now available, and Messrs. Ferranti showed a range of silicon photo-voltaic cells; these have a response time in the microsecond region and have applications in equipments using modulated light. The new cells have a high conversion efficiency and in the larger sizes can be used as solar cells to provide electrical energy from sunlight.

This annual exhibition continues to be well attended and it provides an opportunity for scientific workers in the north-west of Britain to keep abreast of current electronic equipment and components.

\section{UNITED KINGDOM CIVIL SERVICE COMMISSION}

$\mathrm{T}$ HE ninety-third annual report of the Civil Service Commissioners, covering the year April 1, 1958-March 31, 1959, records an increase in the number of candidates successful in open competition from 13,057 to 14,616 , but for the administrative class the number of successful candidates decreased from 39 to 37 , though well above the 1956-57 figures, and some departments were short of recruits, although the number of unfilled vacancies is not large (Report of Her Majesty's Civil Service Commissioners for the period lst April, 1958 to 3lst March, 1959. Pp. 36. (London : H.M. Stationery Office, 1959.) 2s. $6 d$. net).

The Commissioners are continuing their efforts to attract a larger number of good candidates from the universities. Candidates in the limited competition for the administrative class further decreased in number. Recruitment to the senior branch of the foreign service was also disappointing, and the shortage of candidates for the statistician class persists. Less than 50 per cent of the declared vacancies as patent examiner have been filled and there was again a shortage of good candidates for scientific officer, engineering and draughtsmen posts, and many vacancies remain unfilled, particularly through a dearth of physicists. Grave shortages remain in the telecommunications and other electronic fields; however, there was a small increase in the number of candidates in the senior scientific officer competition and most of the vacancies which had been notified were filled.

Applications in the assistant experimental officer/ experimental officer competition remained remarkably steady and generally sufficient candidates were successful to meet departmental needs. The supply of biologists again exceeded the limited demand. The research fellowship competition continued to attract interest from workers in all fields of research, and thirteen candidates were offered the award. There is some evidence that it is becoming harder to attract good applicants for junior fellowships.

Results of interviews in Ottawa and Washington in April 1958 to select applications for research fellow. ships and scientific officer posts were less satisfactory than originally appeared likely, and in the event only one candidate joined the Service as Research Fellow and one as a senior scientific officer, although some well-qualified men appear to have been stimulated to return to Great Britain in the universities or in industry.

\section{EUROPEAN NUCLEAR ENERGY RESEARCH}

$\mathrm{T}$ THE seventh annual report of the Netherlands'Norwegian Joint Establishment for Nuclear Energy Research*, describing the work of the Establishment during the period July 1, 1957-June 30, 1958, mentions that the research reactor, Jeep, was in almost continuous operation at $450 \mathrm{~kW}$. during the year, with a total release of heat of $105 \cdot 6 \mathrm{MW}$. days, but that the corrosive effects of the heavy water have grown worse and a minor leakage of heavy water occurred during April. The completion of the Halden boiling water reactor, which is an Institutt for Atomenergi project and which is situated inside a rock excavation near the paper pulp factory, Saug-

* Seventh Annual Report, July 1957-June 1958, of the Netherlands'. Norwegian Joint Establishment for Nuclear Energy Research. Pp. 32. (Kjeller near Lillestrøm: Netherlands'-Norwegian Joint Establishment for Nuclear Energy inesearch, 1959.) brugsforeningen, will be delayed by about a year because of construction and design problems. The reactor tank was completed during the spring of 1958. The necessary amount of heavy water which was purchased from the United States of America is now stored at Halden, and part of the uranium ordered from Great Britain has been delivered. An agreement between Norway, Denmark, Sweden, Austria, Great Britain, Switzerland and Euratom, on the joint operation of the reactor, was signed by representatives on June 11, 1958.

Because of the higher demand for radioisotopes, and technical improvements in the production system, the number of isotope deliveries from Kjeller to customers outside the Establishment increased by 33 per cent over the previous year. The deliveries 